by creating networks of researchers to support national projects such as the Megabank. Although he credits Nakamura as a brilliant scientist, he adds that his strengths lie more in research than administration and networking.

Atsushi Sunami, a science-policy researcher at the National Graduate Institute for Policy Studies in Tokyo, blames Nakamura's departure on bureaucracy and a lack of political leadership, rather than a fundamental problem with medical innovation. "I think he just couldn't handle the system" of Japanese government, Sunami says.

When Nakamura returned to Japan in 1989 from a position at the Howard Hughes Medical Institute at the University of Utah in Salt Lake City, he says, his ambition "was to make drugs in Japan and provide them to Japanese patients".
But now, he says, "if I stay, I wouldn't be able to make anything. By moving to the United States, I might be able to bring something back." -

1. Cyranoski, D. Nature 424, 359 (2003).

. Cyranoski, D. Nature 464, 22-24 (2010)

3. The International HapMap Consortium Nature 437, 1299-1320 (2005).

4. Cyranoski, D. Nature 443, 382 (2006).

5. Cyranoski, D. Nature 474, 136 (2011).

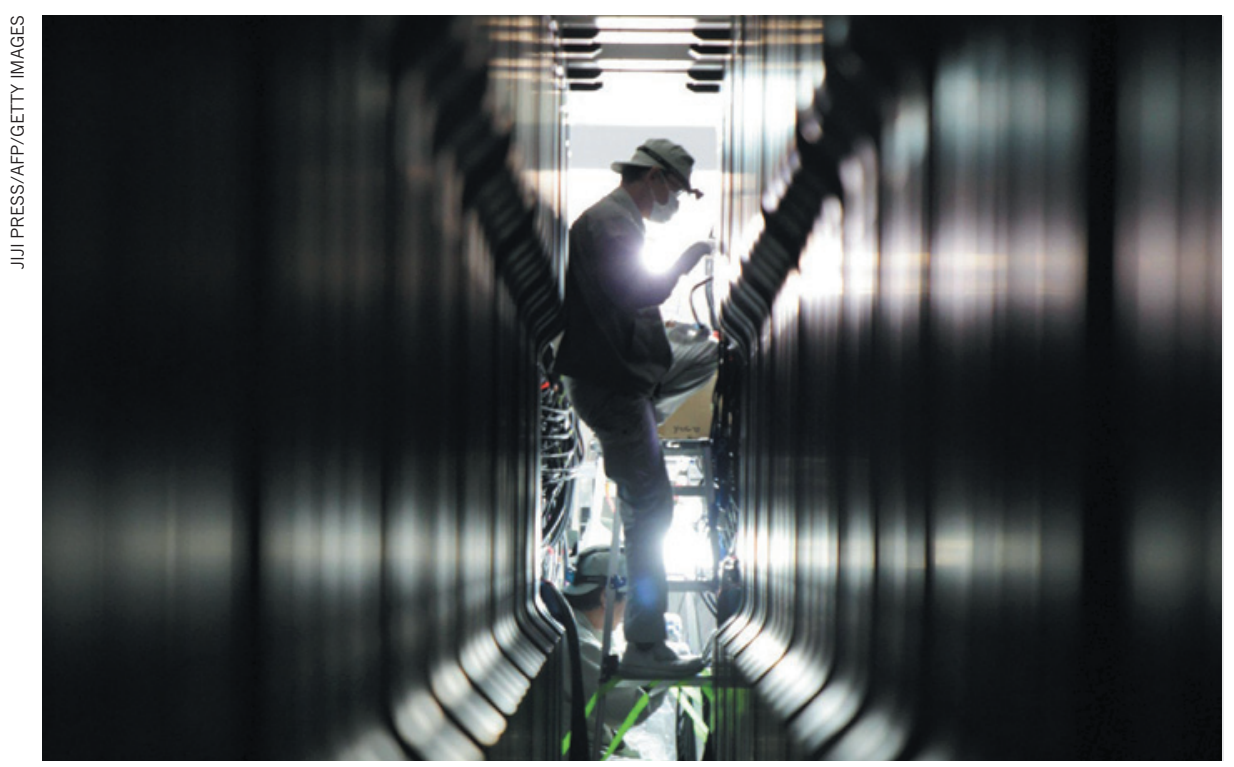

RIKEN, home to the world's fastest supercomputer (above), may be overseen by a new body.

RESEARCH POLICY

\section{Japan plans to merge major science bodies}

\section{Drive to save money could increase bureaucracy.}

\section{BY ICHIKO FUYUNO}

$\mathrm{I}$ Japan's government is gearing up to make cost savings through a root-and-branch reform of the country's science system, merging some of its most prominent research organizations.

Plans approved by the government's cabinet on 20 January would consolidate the RIKEN network of basic-research laboratories with the National Institute for Materials Science (NIMS), the Japan Agency for Marine-Earth Science and Technology (JAMSTEC), the National Research Institute for Earth Science and Disaster Prevention (NIED) and the Japan Science and Technology Agency (JST) - the national funding body.

"This is the result of our aim to create the n its battle against a sluggish economy, world's leading science and technology while slashing wasteful spending and making the organization as compact as possible," said Tenzo Okumura, a senior vice-minister of the education and science ministry, at a press conference last week. The policy would probably create an overarching body to supervise all five institutions, which would share more of their research and administrative resources, and lose some of their executive directors.

But with few details about the timing, potential cost savings or full implications of the change, many researchers are concerned that it could be a recipe for harsh funding cuts and even greater bureaucracy.

"The plan isn't intended to improve the research system," says Tasuku
DNATURE.COM

For more from

this region, see

Nature Japan:

natureasia.com/japan
Honjo, a molecular biologist at Kyoto University and a former member of the Council for Science and Technology Policy, the government's top science advisory body. "Each of the institutes has fundamentally different characteristics, so I feel they would be very difficult

JST president Michiharu Nakamura, however, is optimistic about the change. "The new organization will be expected to play the main part in leading the national innovation," he says. "We will work hard to keep the independence of our fund-distribution process after the integration, as well as to strengthen the cooperation between stakeholders such as the academic community and industries." The plan would also merge the National Institute of Radiological Sciences (NIRS) with the Japan Atomic Energy Agency. The government says that this will speed up and strengthen its commitment to mitigating the Fukushima accident, and help to improve nuclear safety measures.

The news comes as the government scrambles to gain public support for tax hikes while cutting public spending. Since the Democratic Party of Japan took power in 2009, the Government Revitalization Unit (GRU), a budget watchdog chaired by the prime minister, has been reviewing government-funded projects and organizations to find savings (see Nature http://doi.org/bs75dv; 2010).

"The GRU rapidly came up with the plan a month ago and pushed forward without much discussion," says Atsushi Sunami, a sciencepolicy specialist at the National Graduate Institute for Policy Studies (GRIPS) in Tokyo. Legislation to enact the overhaul will be submitted to Japan's parliament, the Diet, in the coming months. If passed, the changes would take effect in April 2014. More institutes may be added to the integration plan during discussions in the Diet, say policy experts.

The government also intends to set up a third-party audit system to evaluate administration and performance more strictly. The idea of more governance worries Sukekatsu Ushioda, president of NIMS. "Currently, the NIMS president has sufficient authority, so the decisionmaking process is fast. We at NIMS can often take new actions shortly after a board meeting," he says. "But if a higher management is added above NIMS, the decision-making would be slower and it would be difficult to take dynamic approaches." to integrate effectively." 